\title{
Sharks eating mosasaurs, dead or alive?
}

\section{B.M. Rothschild ${ }^{1,2,3,}{ }^{*}$, L.D. Martin ${ }^{3} \&$ A.S. Schulp ${ }^{4,5}$}

1 Arthritis Center of Northeast Ohio, 5500 Market Street, Suite 199, Youngstown, Ohio 44512, USA.

2 Northeastern Ohio Universities College of Medicine, Rootstown, 0hio; Carnegie Museum of Natural History, Pittsburgh, Pennsylvania, USA.

3 Kansas Museum of Natural History, Dyche Hall, University of Kansas, Lawrence, Kansas 60645, USA.

4 Natuurhistorisch Museum Maastricht, de Bosquetplein 6, NL-6211 KJ Maastricht, the Netherlands.

5 Faculty of Earth and Life Sciences, Vrije Universiteit Amsterdam, the Netherlands.

* Corresponding author. Email: bmr@neoucom.edu

Manuscript received: August 2004; accepted: September 2004

\section{Abstract}

Shark bite marks on mosasaur bones abound in the fossil record. Here we review examples from Kansas (USA) and the Maastrichtian type area (SE Netherlands, NE Belgium), and discuss whether they represent scavenging and/or predation. Some bite marks are most likely the result of scavenging. On the other hand, evidence of healing and the presence of a shark tooth in an infected abscess confirm that sharks also actively hunted living mosasaurs.

Keywords: Mosasaurs, Platecarpus, Prognathodon, Tylosaurus, sharks, scavenging, predation

\section{Introduction}

In the Late Cretaceous, during a period of some twenty-five million years, mosasaurs, the often gigantic marine lizards, evolved, diversified and became extinct (Bell, 1997). They shared the seas with other predators, such as sharks. The largest mosasaurs, e.g. some species of Hainosaurus, Tylosaurus, Mosasaurus and Prognathodon, reached lengths in excess of fourteen metres (e.g., Dollo, 1917; Lingham-Soliar, 1992), and although length estimates of almost eighteen metres have been published as well (e.g., Lingham-Soliar, 1995), these highest values should perhaps be regarded with some caution. Regardless of the exact maximum length, in terms of size, mosasaurs were the dominant marine predators of their time.

The dietary habits of mosasaurs are well known. Stomach contents reported include fish (e.g., Williston, 1914; Martin \& Bjork, 1987) and bird remains (Bjork, 1981). Mulder (2003) linked mosasaur attacks to the damage on carapaces of the large marine turtle Allopleuron hofmanni. 'Bite' marks on ammonites, attributed to mosasaurs, are regularly reported (see Tsujita \& Westermann, 2001 and references therein, but also Machalski, 1999, for a different interpretation). Everhart (2004a) described plesiosaur remains as stomach contents in Tylosaurus, but Everhart (2003) also suggested that large sharks preyed on plesiosaurs. Observations on tooth morphology allow for inferences to be made on a mosasaur's diet (e.g., Dollo, 1913; Massare, 1987). Some mosasaurs even preyed upon smaller members of their own family; Williston (1898) suggested, and later finds with stomach contents (e.g., Martin \& Bjork, 1987) have confirmed this, that the large mosasaur Tylosaurus fed on other mosasaurs, including Clidastes.

Although all this suggests that large mosasaurs were the dominant marine predators of the Late Cretaceous seas, it is interesting to review the evidence of shark bite marks on mosasaur bones. Here we present a selection of specimens from Kansas (USA) and the Maastrichtian type area (SE Netherlands, 
NE Belgium), and discuss whether sharks only scavenged mosasaur carcasses, or whether certain sharks also actively hunted on living mosasaurs.

Bite marks on mosasaur bones are widely known (Rothschild \& Martin, 1993; Bell \& Martin, 1995; Bardet et al., 1998; Everhart, 1999, 2004b). Often, these bite marks are attributed to shark scavenging (Mudge, 1877 [cited in Everhart, 2004b]; Williston, 1898, pp. 214, 215). Naturally, it is difficult to distinguish between shark bite marks resulting from scavenging and those resulting from active predation. Only when a mosasaur survived an attack by one or more sharks, and only if the wounds subsequently healed, would evidence of the trauma be recorded in the fossil bones and thus allow conclusions to be drawn.

Except for other mosasaurs, the only animals in the Cretaceous seas large enough to attack adult mosasaurs were probably sharks. Although most Cretaceous sharks did not grow beyond lengths of about three metres, one species, Cretoxyrhina mantelli, measured about five metres in length when adult; very large individuals probably reached over six metres (Shimada, 1997). A recent discovery (FHSM VP-14010) certainly documents that Cretoxyrhina mantelli reached lengths of at least $5.5 \mathrm{~m}$ (Corrado et al., 2003). It should be noted here, too, that a 5-metre shark would have been considerably heavier than a (much more slender) 5-metre mosasaur.

The size range of Cretoxyrhina is analogous to that of the modern Great White shark, Carcharodon carcharias. This is a known predator on seals and whales. Mosasaurs can be considered the Mesozoic ecomorph equivalents of toothed whales (including modern killer whales), so did Cretoxyrhina actively hunt on large mosasaurs, or was it merely a scavenger?

Cretoxyrhina certainly did eat mosasaurs (e.g., Everhart, 2004b). The stomach contents of a relatively small $(3 \mathrm{~m})$ specimen of $C$. mantelli in the University of Kansas Vertebrate Paleontology collection (KUVP 69102, cited by Shimada, 1997), includes two partially digested mosasaur vertebrae. Additional examples have been described by Shimada (1997). However, from stomach contents alone, it is not clear whether the shark had attacked a living mosasaur, or scavenged a carcass. The only direct fossil evidence that the shark did attack living mosasaurs is a healed trauma on the bone of a mosasaur fortunate enough to have survived the attack of such a $6-\mathrm{m}$ shark.

\section{Material and methods}

We macroscopically surveyed material from the University of Kansas collection and at the Natuurhistorisch Museum Maastricht (NHMM) for evidence of trauma. All material from the KUVP described here, comes from the Smoky Hill Chalk Member of the Niobrara Chalk. Although several of the examples are from older collections at the University of Kansas of which the stratigraphic provenance is not entirely clear, it seems almost certain that all are from the Upper or Smoky Hill Member of the Niobrara Chalk Formation (Bardack, 1965; Stewart et al., 1990). The Smoky Hill Member is dated as late Coniacian to earliest Campanian (Hattin, 1982). The material from the type Maastrichtian discussed here is much younger; it all comes from the Lanaye Member of the Gulpen Formation (e.g., Vonhof \& Smit 1996), dated as early late Maastrichtian.

All material was examined for evidence of reparative bone (implying predation), as opposed to unhealed lesions, that do not allow distinction between scavenging and predation. Specimens showing reparative bone were X-rayed, and, in one case (KUVP 1094), sectioned and subjected to an electron probe analysis.

\section{Results and analyses}

Bite marks on mosasaur bones can be subdivided into two categories. One group is composed of long rows of widely spaced puncture wounds, corresponding to the teeth in mosasaur jaws. Most of these are found in the rostral region and probably represent the results of territorial combat (Rothschild \& Martin, 1993; Bell \& Martin, 1995). Long, closely spaced grooves can be confidently attributed to shark bites, especially if they show the typical curvature of the elasmobranch mouth (Schwimmer et al., 1997; Shimada, 1997; Bardet et al., 1998; Everhart, 2004b).

KUVP 1051, a Platecarpus specimen in the University of Kansas collection, shows bite marks on the caudal vertebrae, which provide an idea of the shape of the attacker's dental arcade (Fig. 1). Along these bite marks, only slight bone remodelling is observed, restricted to the edges of the wound.

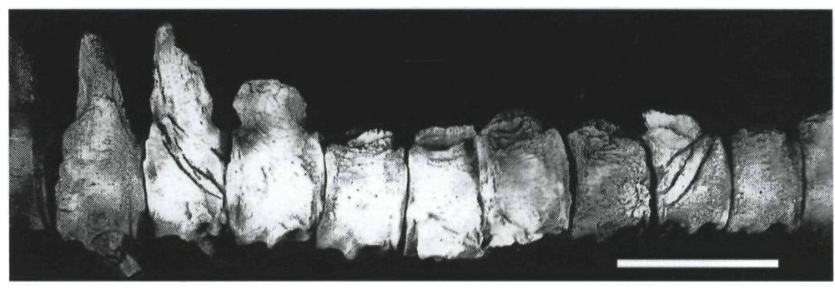

Fig. 1. Long, closely spaced grooves in mosasaur tail (KUVP 1051) illustrating typical curvature of elasmobranch mouth. Scale bar equals $5 \mathrm{~cm}$.

KUVP 1094 is one of the specimens collected by Williston in the nineteenth century and originally identified as Platecarpus. Unfortunately, subsequent study revealed that this registration number included two individuals. One consisted of a fragmentary skull, cervical and dorsal vertebrae of a Platecarpus. This specimen includes matrix assignable to the 'Blue Chalk', as opposed to a second individual that has 'Yellow Chalk' adhering to it. Although discoloration appears to be a weathering phenomenon (e.g., Hattin, 1982), the colour differences here rather seem to indicate that the co-mingled specimens came from different localities. The second individual is represented 


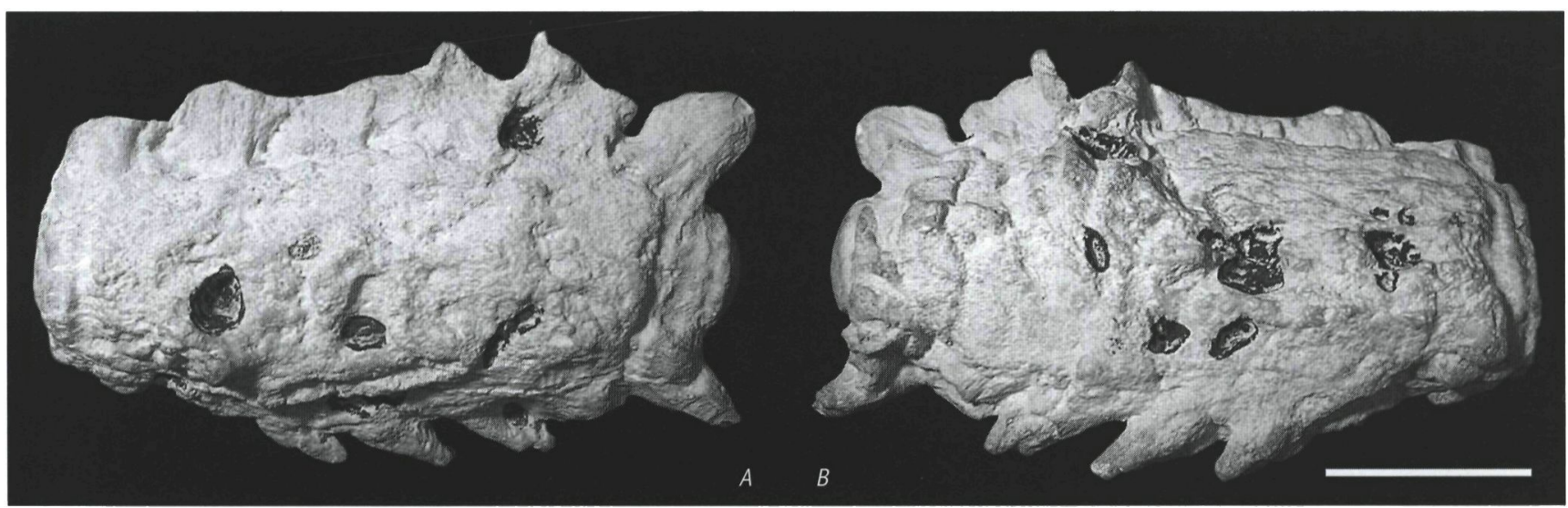

Fig. 2. A - Left lateral; and B - right lateral view of coalesced mosasaur vertebrae (KUVP 1094). Seven and eight depressions respectively, representing tooth marks, are visible. Scale bar equals $5 \mathrm{~cm}$.

by several dorsal vertebrae, an uncrushed caudal, a series of seven coalesced caudal vertebrae and their associated haemal arches. The presence of haemal arches and the absence of transverse processes indicate that these are terminal caudal vertebrae, sensu Russell (1967). The dorsal spines and chevrons do not seem as elongated as in Clidastes. The specimen is about average in size for Platecarpus, but would be small for Tylosaurus (although it could represent a juvenile tylosaur). The fusion of the haemapophyses to the centra and their narrow alignment could support assignment to the Mosasaurinae, but extreme pathologic modification of the caudals make any taxonomic assignment uncertain. We estimate the length of the mosasaur to have been about six metres. The coalesced vertebrae show seven depressions on the right side, which may represent the bite marks of individual teeth, and eight on the left side (Fig. 2). In section (Fig. 3A), these depressions overlie abscesses in the bone. The bone is heavily reorganised from massive infection, with extensive destruction of the vertebral centra and obliteration of the intercentral joints. The abscesses range in size from 5 to $10 \mathrm{~mm}$. In an abscess at the base of one of the puncture wounds is an imbedded tooth tip. The anterior-posterior width of the tooth exposed in the section is $2.5 \mathrm{~mm}$; the transverse width is $7.1 \mathrm{~mm}$. The width of the original tooth base can be estimated by looking at the spacing between punctures (Fig. 2), as the more closely spaced wounds can reasonably be assumed to have been made by adjacent teeth. In living sharks, the tooth bases abut against each other. Two closely defined entry wounds near the front of the bite arcade allow an estimated tooth base width of $14 \mathrm{~mm}$. The arcade on the other side of the vertebrae allows estimates of $19.8 \mathrm{~mm}$ and $21.7 \mathrm{~mm}$. This would not have been a large shark and may account for the mosasaur's survival. A body length of the attacker of somewhat less than three metres seems plausible.

Initially, the shark tooth had been identified by J.D. Stewart as Squalicorax, on the basis of a supposed serration (Rothschild \& Martin, 1993). Further preparation indicates that this was simply an artefact in the edge of the tooth and that the tooth was actually unserrated. Stewart (pers. comm., 1992) points out that the tooth in the abscess was biconvex near its tip, which is characteristic of the genus Cretoxyrhina, noting, 'I was still a bit bothered by the Squalicorax identification, so I studied it some more, and took the liberty of removing a bit more bone on one side. The side I exposed is smooth, and the other side seems to have a nick in it. Even assuming that the nick is a serration, the interval between it and the next notch is abnormally large. Secondly, I cannot find any Squalicorax teeth with a biconvex cross section right at the tip' (see also Shimada, 1997). Shimada (1997) suggested a different interpretation, with a much wider dental arcade, which also better corresponds to the larger Cretoxyrhina rather than the relatively small Squalicorax.

The abscesses in KUVP1094 are filled with sparry calcite, suggesting that they were isolated from the surrounding sediment at the moment of burial. This in turn suggests that the abscesses had been closed by bone growth already during life. Electron probe analysis indicates an unusually high concentration of sulphur, as compared to the region outside of the abscess and on other vertebrae from the Niobrara Chalk. Sulphur is a byproduct of decay, providing further evidence that the abscess was locked from the external environment. These sulphur concentrations were not duplicated on samples of the matrix in sediment-filled cavities in the bone or on surface samples. Further, scanning electron microscopy showed concentrations of coccolithophorids (the resting stage of haptophytes) along the wall of the abscess (Fig. 3B - D).

NHMM 1998141, the holotype of Prognathodon saturator from the type Maastrichtian, clearly shows evidence of scavenging. The total length of this globidensine mosasaur must have been approximately 12 metres. The skeleton is rather disarticulated, with the flippers almost entirely missing, a rather disarticulated tail, and only the skull and trunk relatively well preserved. Several ribs display bite marks, with none of them showing any sign of healing (Dortangs et al., 2002). 


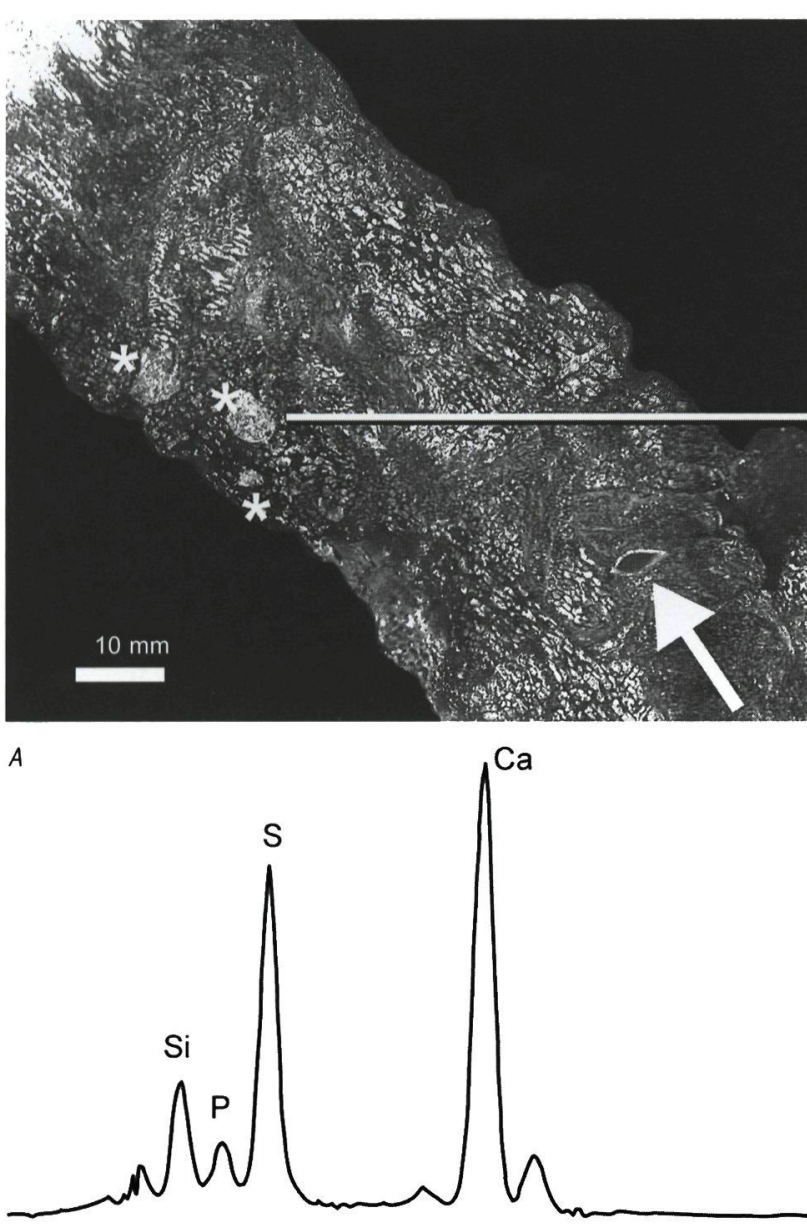

C

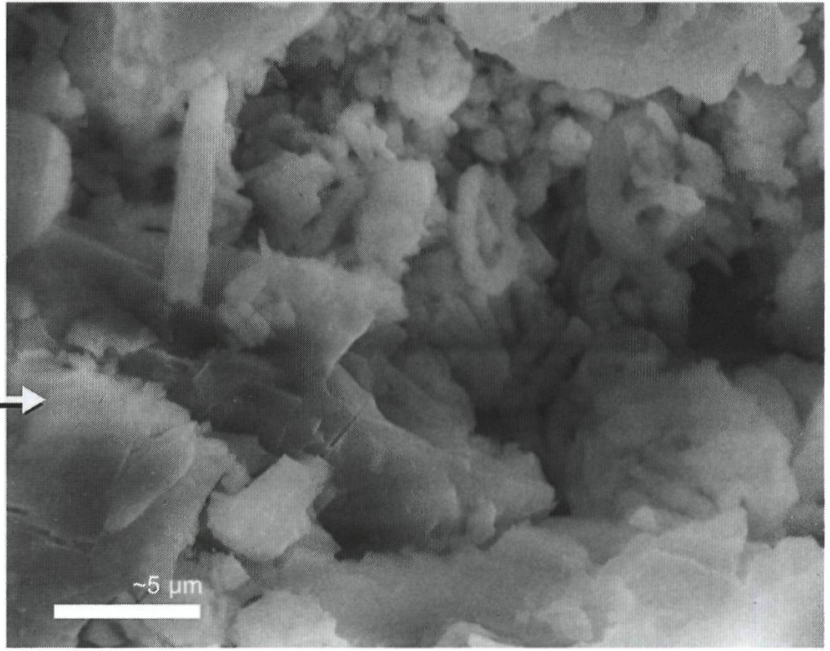

$B$

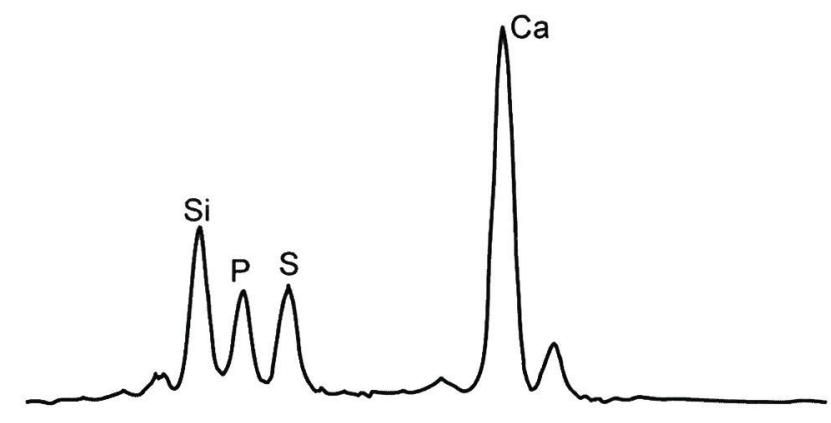

D

Fig. 3. Cross-section of infected vertebrae, KUVP 1094, revealing disorganised bone with embedded shark tooth fragment (arrow) and abscesses (asterisks) (A); SEM photograph of coccolithophorids in abscess (B). Electron probe analysis indicates that the sulphur content in the abscess (C) is much higher than in the external surface of the bone $(D)$.

On various occasions, Squalicorax has been implicated in scavenging on mosasaur carcasses (e.g., Schwimmer et al., 1997; Kass, 1999; Everhart, 2004b). Considering the fact that the largest sharks in the type Maastrichtian seas did not grow much beyond three metres, it appears unlikely that NHMM 1998141 was killed by sharks. Rather, a natural death, either by age or disease, appears a more likely explanation. Associated shed teeth allow to attribute the scavenging to Squalicorax and Plicatoscyllium.

Other material - An additional survey of the mosasaur collections of the Natuurhistorisch Museum Maastricht by the first and third author did not yield any evidence of healed shark bite marks. Previously, bite marks attributable to Centrophoroides appendiculatus on a median caudal vertebra of the up to 6-metre long Plioplatecarpus marshi were described by Bardet et al. (1998), but these bite marks are considered to have been the result of scavenging. Everhart (1999) discussed FHSM VVP13750, a 'twice-bitten' distal end of the tail of a mosasaur from the Smoky Hill Chalk. It consists of 25 caudal vertebrae and a fused distal segment that includes at least five vertebrae (total length about $60 \mathrm{~cm}$ ). All of the vertebrae are partially digested and some appear to have been bitten through (the result of several bites by the predator, most likely a large shark). The specimen represents an earlier attack that probably removed the tip of the mosasaur's tail, resulting in an infection that fused the five posteriormost remaining vertebrae, which healed over a fairly long period of time (similar to KUVP 1094), and then suffered another attack (equally likely to have been the result of a fatal encounter with a shark, or scavenging). Everhart (1999) described another Platecarpus specimen from the KU collections (KUVP 4862), which preserves unhealed Cretoxyrhina bite marks on the skull and dorsal vertebrae.

\section{Discussion}

The amount of bone repair in KUVP 1051 is minimal. The slight bone remodelling, restricted to the edges of the wound confirms that the mosasaur survived the attack - it takes at least two weeks for bones to manifest any sign of visible reaction (Resnick, 2002). Absence of more extensive remodelling 
suggests that the mosasaur died soon after. The location of the bite marks provides clues to the morphology of the shark's dental arcade. The orientation of the bite marks suggests that the attack was directed downwards towards the upper surface of the tail.

KUVP 1094 shows the effects of massive infection. Because the tail is the main swimming organ of mosasaurs (Massare, 1997; Mulder, 2001), serious injury would have been debilitating. Williston (1898, p. 214) even stated, 'Never have I known of a case where there has been evidence of ante-mortem loss of the tail or any part of it.' Even without the effects of infection, it would have made the mosasaur more vulnerable to further predation. The possibility that coccolithophorid algae were responsible for the infection in KUVP 1094 should be considered with the cautionary note that much of the Niobrara Chalk is composed of the skeletal parts (coccoliths) of these organisms. Although we do not have other examples of haptophyte infections, there are examples of algal infections following puncture wounds (Connole, 1990). So far, the literature on contemporary shark bites is too limited to provide much insight into the fossil examples (Buck et al., 1984).

The attacks described here were directed from above the mosasaur and the shark and mosasaur were meeting each other, rather than the shark pursuing from behind. (0f course, if the mosasaur was ascending from a dive while it was bitten, the attack would have been directed from the 'back'). This suggests that the mosasaur was swimming at some depth before the encounter and perhaps met the shark while surfacing. In at least one case (KUVP 1094), the angle of the shark attack is strongly inclined to the mosasaur vertebral column.

What can we learn from shark injuries on mosasaurs? The survived injuries described here are from sharks between two and three metres in length. Attacks from larger sharks (if any) were probably fatal, e.g. in FHSM VP-13283, figured by Shimada (1997, fig. 4), that includes five vertebrae severed from the middle of the back of a 7-metre mosasaur. The mosasaurs that survived bite injuries are not large, ranging in length from five to seven metres. All of these survived bites are on the tail. It seems likely that attacks including bites elsewhere were normally fatal. Survival of the mosasaur suggests that it successfully defended itself. Sharks may have geared their attacks to moments when the mosasaur was more vulnerable.

A 6-metre Cretoxyrhina in the University of Kansas collections (KUVP 68979) has $>124$ gastroliths associated with it (Everhart, 2000). These could only have come from ingestion of part of a long-necked plesiosaur (elasmosaurid) and provides evidence that sharks also fed on those huge animals. Shimada \& Hooks (2004) reported Cretoxyrhina bites on large marine protostegid turtles. While those examples do not permit distinguishing between an attack on a live individual and carcass scavenging, it does provide additional evidence to support the suggestion that Cretoxyrhina ate large marine reptiles.
By the onset of the late Campanian, Cretoxyrhina mantelli had become extinct (Stewart, 1990; but see also Siverson, 1992), leaving the mosasaurs behind as the dominant marine predators. An additional survey of the Natuurhistorisch Museum Maastricht collections, which houses much younger (mainly Maastrichtian and some late Campanian) mosasaur remains, did not yield any evidence of healed shark bite marks. The largest sharks known from the Maastricht seas were Squalicorax, which reached an estimated maximum length of about three metres, and the similar-sized or perhaps slightly larger Cretalamna appendiculata. Although absence of evidence is not necessarily evidence of absence, it is tempting to assume that by the end of the Cretaceous, mosasaurs had finally established themselves as the exclusive top predator in the marine ecosystem, having no other animals to fear other than mosasaurs. We are, however, fully aware that this study represents two snapshots in space and time only, so more work on other collections is certainly needed in order to obtain a more complete picture.

\section{Acknowledgements}

Many thanks to J.D. Stewart for comments on sharks and mosasaurs, and to M.J. Everhart for discussion of shark predation. J.W.M. Jagt and D. Kroon provided helpful comments on an earlier version of the manuscript. The feedback from reviewers J. Lindgren and M.J. Everhart has greatly improved this paper, and their help is gratefully acknowledged.

\section{References}

Bardack, D., 1965. Localities of fossil vertebrates obtained from the Niobrara Formation (Cretaceous) of Kansas. University of Kansas Publications, Museum of Natural History 17: 1-14.

Bardet, N., Jagt, J.W.M., Kuypers, M.M.M. \& Dortangs, R.W., 1998. Shark tooth marks on a vertebra of the mosasaur Plioplatecarpus marshi from the Late Maastrichtian of Belgium. Publicaties van het Natuurhistorisch Genootschap in Limburg 41: 52-55.

Bell, G.L. Jr., 1997. Mosasauridae. In: Callaway, J.M. \& Nicholls, E.L. (eds): Ancient marine reptiles. Academic Press (San Diego): 281-292.

Bell, G.L. Jr. \& Martin, J.E., 1995. Direct evidence of aggressive intraspecific competition in Mosasaurus conodon (Mosasauridae: Squamata). Journal of Vertebrate Paleontology 15 (Suppl. to 3): 18A.

Bjork, P.R., 1981. Food habits of mosasaurs from the Pierre Shale of South Dakota. GSA, Abstracts with Program (Rocky Mountain Section, Rapid City) 13: 191.

Buck, J.D., Spotte, S. \& Gadbaw, J.J. Jr., 1984. Bacteriology of the teeth from a great white shark: potential medical implications for shark bite victims. Journal of Clinical Microbiology 20: 849-851.

Connole, M.D., 1990. Review of animal mycoses in Australia. Mycopathologia 111: $133-164$

Corrado, C.A., Wilhelm, D.A., Shimada, K. \& Everhart, M.J., 2003. A new skeleton of the Late Cretaceous lamniform shark, Cretoxyrhina mantelli, from western Kansas. Journal of Vertebrate Paleontology 23 (Suppl. to 3): 43A. 
Dollo, L., 1913. Globidens Fraasi, mosasaurien mylodonte nouveau du Maestrichtien (Crétacé supérieur) du Limbourg, et l'éthologie de la nutrition chez les mosasauriens. Archives de Biologie 28: 609-626.

Dollo, L., 1917. Les vertébrés vivants et fossiles. Guide du Touring Club de Belgique 2: 126-161.

Dortangs, R.W., Schulp, A.S., Mulder, E.W.A., Jagt, J.W.M., Peeters, H.H.G. \& de Graaf, D.Th., 2002. A large new mosasaur from the Upper Cretaceous of The Netherlands. Netherlands Journal of Geosciences 81: 1-8.

Everhart, M.J., 1999. Evidence of feeding on mosasaurs by the Late Cretaceous lamniform shark, Cretoxyrhina mantelli. Journal of Vertebrate Paleontology 17 (Suppl. to 3): 43A, 44A.

Everhart, M.J., 2000. Gastroliths associated with plesiosaur remains in the Sharon Springs Member of the Pierre Shale (Late Cretaceous), Western Kansas. Transactions of the Kansas Academy of Sciences 103: 58-69.

Everhart, M.J., 2003. First records of plesiosaur remains in the lower Smoky Hill Chalk Member (Upper Coniacian) of the Niobrara Formation in western Kansas. Transactions of the Kansas Academy of Sciences 106: 139-148.

Everhart, M.J., 2004a. Plesiosaurs as the food of mosasaurs; new data on the stomach contents of a Tylosaurus proriger (Squamata; Mosasauridae) from the Niobrara Formation of western Kansas. The Mosasaur 7: 41-46.

Everhart, M.J., 2004b. Late Cretaceous interaction between predators and prey. Evidence of feeding by two species of shark on a mosasaur. PalArch 1: 1-6.

Hattin, D.E., 1982. Stratigraphy and depositional environment of the Smoky Hill Chalk Member, Niobrara Chalk (Upper Cretaceous) of the type area, western Kansas. Kansas Geological Survey Bulletin 225: 1-108.

Kass, M.S., 1999. Prognathodon stadtmani (Mosasauridae): A new species from the Mancos Shale (Lower Campanian) of Western Colorado. Utah Geological Survey, Miscellaneous Publications 99: 275-294.

Lingham-Soliar, T., 1992. The tylosaurine mosasaurs (Reptilia, Mosasauridae) from the Upper Cretaceous of Europe and Africa. Bulletin de l'Institut royal des Sciences naturelles de Belgique, Sciences de la Terre 62: 171-194.

Lingham-Soliar, T., 1995. Anatomy and functional morphology of the largest marine reptile known, Mosasaurus hoffmanni (Mosasauridae, Reptilia) from the Upper Cretaceous, Upper Maastrichtian of The Netherlands. Philosophical Transactions of the Royal Society of London B347: 155-180.

Machalski, M., 1999. Mosasaur bites or punctured limpet home scars? Acta Palaeontologica Polonica 44: 347, 348.

Martin, J.E. \& Bjork, P.R., 1987. Gastric residues associated with a mosasaur from the Late Cretaceous (Campanian) Pierre Shale in South Dakota. In: Martin, J.E. \& 0strander, G.E. (eds): Papers in vertebrate paleontology in honor of Morton Green. Dakoterra 3: 68-72.

Massare, J.A., 1987. Tooth morphology and prey preference of Mesozoic marine reptiles. Journal of Vertebrate Paleontology 7: 121-137.

Massare, J.A., 1997. Faunas, behaviour, and evolution. Introduction. In: Callaway, J.M. \& Nicholls, E.L. (eds): Ancient marine reptiles. Academic Press (New York/London): 401-421.

Mudge, B.F., 1877. Notes on the Tertiary and Cretaceous periods of Kansas. In: Ninth Annual Report, United States Geological and Geographical Survey of the Territories (Hayden) 1875, Part I (Geology): 277-294.

Mulder, E.W.A., 2001. Co-ossified vertebrae of mosasaurs and cetaceans: implications for the mode of locomotion of extinct marine reptiles. Paleobiology 27: 724-734.
Mulder, E.W.A., 2003. Comparative osteology, palaeoecology and systematics of the Late Cretaceous turtle Allopleuron hofmanni (Gray 1831) from the Maastrichtian type area. Publicaties van het Natuurhistorisch Genootschap in Limburg 44: 23-92.

Resnick, D., 2002. Diagnosis of bone and joint disorders (4th ed.). W.B. Saunders (Philadelphia): 5472 pp.

Rothschild, B.M. \& Martin, L.D., 1993. Paleopathology: disease in the fossil record. CRC Press (London): 386 pp.

Russell, D.A., 1967. Systematics and morphology of American mosasaurs. Bulletin of the Peabody Museum of Natural History, Yale University 23: 1-241.

Schwimmer, D.R., Stewart, J.D. \& Williams, G.D., 1997. Scavenging by sharks of the genus Squalicorax in the Late Cretaceous of North America. Palaios 12: 71-83.

Shimada, K., 1997. Paleoecological relationships of the Late Cretaceous lamniform shark, Cretoxyrhina mantelli (Agassiz). Journal of Paleontology 71: 926-933.

Shimada, K. \& Hooks, G.E. III, 2004. Shark-bitten protostegid turtles from the Upper Cretaceous Mooreville Chalk, Alabama. Journal of Paleontology 78: 205-210.

Siverson, M., 1992. Biology, dental morphology and taxonomy of lamniform sharks from the Campanian of the Kristianstad Basin, Sweden. Palaeontology 35: 519-554.

Stewart, J.D., Bennett, S.C. \& Zakrzewski, R.J., 1990. Road log from Lawrence to the type area of the Niobara Chalk - October 9 - 10, 1990. In: Bennett, S.C. (ed.): Niobrara Chalk Excursion Guidebook, Society of Vertebrate Paleontology. Museum of Natural History and Kansas Geological Survey (Lawrence, Kansas): 3-12.

Stewart, J.D., 1990. Niobrara Formation vertebrate stratigraphy. In: Bennett, S.C. (ed.): Niobrara Chalk Excursion Guidebook, Society of Vertebrate Paleontology. Museum of Natural History and Kansas Geological Survey (Lawrence, Kansas): 19-30.

Tsujita, C.J. \& Westermann, G.E.G., 2001. Were limpets or mosasaurs responsible for the perforations in the ammonite Placenticeras? Palaeogeography, Palaeoclimatology, Palaeoecology 169: 245-270.

Vonhof, H.B. \& Smit, J., 1996. Strontium-isotope stratigraphy of the type Maastrichtian and the Cretaceous/Tertiary boundary in the Maastricht area (SE Netherlands). In: Brinkhuis, H. \& Smit, J. (eds): The Geulhemmerberg Cretaceous/Tertiary boundary section (Maastrichtian type area, SE Netherlands). Geologie en Mijnbouw 75: 275-282.

Williston, S.W., 1898. Mosasaurs. The University Geological Survey of Kansas 4, 83-221.

Williston, S.W., 1914. Water reptiles of the past and present. Chicago University Press (Chicago): 251 pp.

\section{Institutional abbreviations}

FHSM - Fort Hays State University, Sternberg Museum of Natural History, Hays, Kansas, USA.

KUVP - University of Kansas Museum of Natural History, Lawrence, Kansas, USA.

NHMM - Natuurhistorisch Museum Maastricht, Maastricht, the Netherlands. 